\title{
Principles of Policymaking in the European Union: \\ An Economic Perspective
}

\author{
Guido Tabellini*
}

\begin{abstract}
How should tasks be divided between the EU and its member states? And what institutional reforms are needed? This paper argues that the single market remains to be better enforced, and this might require further centralisation of tasks. On the other hand, EU meddling with redistribution should be scaled back; this would imply reducing EU intervention in agricultural policy, structural funds and the social charter. EU tasks should instead be expanded outside the first pillar, namely in foreign and defence policies, internal security, immigration. The paper ends by discussing what institutional reforms are needed to accompany this allocation of tasks. (JEL F02, F3)
\end{abstract}

\section{Introduction}

What tasks should the European Union have, which ones should be left to Member States? What is the appropriate decision making procedure for the tasks assigned to the European level of government? In particular, what roles should be given to the Commission and to the Council? These are some of the more difficult and pressing questions addressed by the ongoing Convention on the Future of Europe.

This paper discusses some of these issues from an economic perspective, with no pretence of completeness. Section 2 summarises the principles of optimal task allocation implied by the traditional theory of fiscal federalism. Section 3 provides a normative assessment of the current EU situation and formulates suggestions for how to reallocate tasks. These reallocations raise specific institution design problems, discussed in Section 4. The paper ends in Section 5 with a discussion of the possible compromises.

* Address: Bocconi University, Via Salasco 5, 20136 Milano.

Presented at the Munich Economic Summit, 7-8 June 2002. Some of the ideas in this paper are also discussed in Tabellini (2002). I am grateful to two anonymous referees, Carlo Bastasin, Erik Berglof, Marco Buti, Barry Eichengreen, Michael Emerson, Wolfgang Hager, Stefano Micossi, Mario Nava, Gerard Roland, Luigi Spaventa, Charles Wyplosz and participants in a meeting of EuropEos for helpful discussions and comments. Of course, I am the only one responsible for the views contained herein. 


\section{Some principles: optimal task allocation in a federation}

Which tasks ought to be centralised? This is a classic question in the economic theory of federalism, addressed by a large literature (for instance Oates, 1999). Obviously, the EU is not a federation. But since so much has been written on the theory of fiscal federalism, it is useful to start from here. Neglecting political complications (i.e. assuming benevolent governments), the answers suggested by the literature can be summarised as follows.

i) A single market. The central government ought to enforce a well functioning common market, removing all barriers to trade within the federation. This includes having fixed exchange rates.

ii) Stabilisation policies. Macroeconomic stabilisation policies ought to be centralised. A common monetary policy is a by-product of fixed exchange rates. And a common fiscal policy is appropriate to respond to aggregate shocks. Idiosyncratic shocks could be dealt with by means of local stabilisation policies, though this could lead to incentive problems as local governments would neglect spillover effects to other localities.

iii) Public goods. Centralising public good provision entails a trade-off. On the one hand, centralisation implies that spillover effects on other localities are fully internalised and economies of scale are fully exploited. On the other hand, decentralisation makes it easier to cope with heterogeneity of preferences among localities and to exploit local information. Public goods with large spillover effects (i.e., large external effects on other localities) and large economies of scale, such as defence, foreign policy, law enforcement, ought to be centralised. Public goods where the spillover effects or the economies of scale are weaker and heterogeneity of preferences is more likely, such as education, ought to be decentralised.

Note that this trade-off suggests that centralisation is likely to be carried out further in smaller states, since heterogeneity of preferences is less likely to be a problem. This in turn also suggests that there might be some contradictions between the European goals of enlargement and deepening: a larger Europe increases the relevance of heterogeneity and thus reduces the desirability of centralisation (Alesina, Angeloni and Etro, 2001 elaborate more on this point).

An important practical issue here is who bears the burden of the proof: whether the advocates of centralisation or of decentralisation. The "principle of subsidiarity", sometimes also called the "principle of decentralisa- 
tion", states that the burden of proof stays with the advocates of centralisation. ${ }^{1}$

iv) Redistribution. Redistribution ought to be centralised. Mobility of tax bases would otherwise constrain the extent of feasible redistribution. And income heterogeneity across localities can only be offset through centralised redistribution. There is an argument in favour of some element of decentralisation, though: decentralisation makes it easier to experiment with alternative social programs (though in principle a central government too could experiment).

\section{What should the EU be doing?}

The EU is not a federation and its political institutions differ in important ways from those of a representative democracy. Moreover, European citizens do not have a common identity and are not prepared to accept common policies imposed under majority rule as they instead do inside each Member State. Nevertheless, the previous guidelines are a useful benchmark against which to contrast the current allocation of tasks in the EU.

But to answer the normative question of optimal task allocation, one has to move beyond the simplistic view of governments as benevolent social planners implicit in the prescriptions of Section 2. We have to take into account the likely political failures at the national and EU level, and more generally the incentives and constraints of politically motivated governments. This is particularly relevant in the case of redistributive policies, since redistributive programs are likely to largely reflect political expediency rather than normative considerations.

In this Section I consider each of the broad policy areas mentioned above, first briefly summarising the status quo, and then trying to identify desirable directions of reform in task allocation.

\subsection{The Single Market}

Free and undistorted trade between EU member states is one of the over-riding principle upon which the EU has been built. Tariffs and non tariff barriers on

1 More precisely, with regard to the EU the principle of subsidiarity says that the Union should take action only in so far as the objectives of the proposed action cannot be sufficiently achieved by the Member States; the principle of proportionality, sometimes invoked when discussing the allocation of tasks between the EU and Member States, says that any action by the Union should not go beyond what is necessary to achieve the objectives of the Treaty. 
goods imported from other Member States are strictly prohibited in the EU, and the EU already has a common trade policy with regard to the rest of the world. A single market for goods is already a reality for the EU.

Yet, Member States face continuing temptations to side-step the principle of free and undistorted trade within the Union, in order to protect domestic producers from their EU competitors. Since any tariff can be decomposed into a consumption tax and a production subsidy, enforcement of free trade inside the EU requires some constraints on national consumption taxes and on production subsidies. Local governments must be prevented from imposing higher consumption taxes on goods that are mainly imported from other localities, and from providing production subsidies and state aids to sectors where foreign competition is intense. This is one of the important tasks of European competition policy.

The need for a strong role of the European level of government in implementing the single market is acknowledged by the European Parliament resolution on the division of competences between the EU and the Member States, European Parliament (2002). In that document, competition policy and the internal market (including the 'four freedoms' and financial services) are correctly included among the Union's own competences, on which the Union has strong and flexible powers while the Member States may intervene only in accordance with the conditions and within the limits established by the Union.

While free trade in goods is a reality inside the EU, this is not yet true for services. The reason is the persistence of national regulatory barriers. Member States have regulatory authority over the provision of many services, such as financial services, public utilities, transportation. Even if national regulation aims to achieve legitimate national political goals (such as guaranteeing universal public provision of essential services), it often erects costly or insurmountable barriers to trade in services. In many instances, achieving a well functioning single market in services requires choosing between one of two alternatives: either accepting the principle of mutual recognition and thus accepting the competition of producers formally incorporated in other localities and subject to other regulatory standards; or else, if this would lead to excessive regulatory competition, abandoning national regulation in favour of centralised regulation at the level of the EU.

But centralising regulation to the EU level or creating new legislation for a single market in services might conflict with the subsidiarity principle: why should national governments or legislators be willing to transfer to Brussels regulatory authority over such delicate areas as energy, banking or telecommunications? The dilemma is made worse by enlargement, and the resulting increase in the number of national legislators or regulators and in the heteroge- 
neity of goals and specific situations. In these areas there is no easy and general solution. The subsidiarity principle might conflict with the goal of creating a well functioning market for services. If so, priority should be given to the completion of the single market.

\subsection{Stabilisation policies}

There is a common monetary policy among the Euro countries. Fiscal policy for stabilisation purposes remains a national prerogative, but within the constraints imposed by the Stability and Growth Pact. Moreover, national fiscal policies are subject to reciprocal screening and monitoring within the EU, not just to guarantee respect of the Stability Pact, but also to insure a minimum of co-ordination and the achievement of some common goals (the so called "broad economic policy guidelines").

\section{Co-ordination to stabilise aggregate demand}

Some commentators have advocated tighter procedures for fiscal policy coordination, to achieve more effective discretional aggregate demand management in reaction to EU wide aggregate shocks, or to achieve a better coordination between monetary and fiscal policies inside the Euro area (see for instance Jacquet and Pisany-Ferry, 2001). But the claim is not convincing, for two reasons.

First, the evidence suggests that the spillover effects across countries in the realm of fiscal stabilisation policies are small and unstable (Gros and Hobza, 2001; European Forecasting Network, 2002): on average, fiscal policy in one country of the Union does not have quantitatively relevant effects in other Member States. The benefits of fiscal co-ordination are accordingly negligible, even though things might change if economic integration proceeds further. Moreover, the possibility of policy co-ordination and communication between national governments already exists and could be exploited if necessary. A problem often mentioned is that nobody is currently entitled to speak as $\mathrm{Mr}$. Euro with sufficient authority and continuity in the event of a currency misalignment. But this is a relatively minor problem, which certainly does not justify a transfer of powers to Bruxelles.

A second reason is that, even if the spillover effects were sizeable, the benefits of an active and discretional fiscal policy for stabilisation purposes are highly doubtful. Evidence by Buti, Franco and Ongena (1997) and in the Commission report Public Finances in EMU 2001 (European Economy 2001-3) shows that fiscal policy is often pro-cyclical; Fatas and Milhov (2001) study a large sample 
of countries and show that, when fiscal policy was used discretionally, it tended to destabilise the economy rather than vice versa. This is not surprising. Fiscal policy operates with uncertain but considerable lags, and it is very difficult to time fiscal policy appropriately over the business cycle. Moreover, governments often engage in "electoral policy cycles": according to evidence in Persson and Tabellini (2003), in a large sample of parliamentary democracies taxes are cut by almost $1 / 2$ percent of GDP during a typical election year. The ideal arrangement is one in which national governments mainly rely on "automatic stabilisers", rather than on discretional policy decisions. Note that, given the large European welfare states, automatic stabilisers are quite large in the Euro area (though they differ across countries). For instance, on the basis of the OECD and Commission estimates, the ECB reports that on average a reduction in the growth rate of GDP of 1 percent implies a worsening of the budget balance by about $1 / 2$ percent of GDP on average (ECB Monthly Bulletin, April 2002; see also Public Finances in EMU 2001 [European Economy 2001-3]).

Overall, the idea that there is a strong role for discretional fiscal policy coordination in Europe is simply without empirical and theoretical foundations (this conclusion is also stressed by Alesina et al., 2001). On the contrary, theoretical work has suggested that fiscal policy co-ordination could even be counter productive (Vaubel, 1985; Tabellini, 1990). In fact, in the only case where the Commission has tried to impose a co-ordinated fiscal policy on a reluctant country, Ireland, its recommendations seemed unnecessary. If the benefits of policy co-ordination are negligible, decisions on these matters are better left in the hands of national governments, and there is no need to transfer sovereignty to the centre.

\section{Co-ordination and the Stability and Growth Pact}

There is also a second argument in favour of fiscal policy co-ordination inside the EU, based not on the alleged benefits of discretional aggregate demand management, but on the enforcement of the Stability Pact. The argument goes something as follows. To let the automatic stabilisers work fully, and given the constraints of the Stability Pact, we need countries to be sufficiently far away from the 3 percent ceiling on budget deficits, ideally close to budget balance. Currently this requirement is not satisfied by a number of countries. The EU should thus have a role in co-ordinating and pushing Member Sates towards the target of a balanced budget on average over the medium run. Implicitly motivated by these considerations, in its recent Communication to the Convention (Commission, 2002a), the Commission advocated a strengthening of its role of agenda setter for macroeconomic policy co-ordination and enforcer of the Stability Pact. Specifically, the Commission suggests that "the major economic policy guidelines and the opinions on the stability and convergence 
programmes should be drafted on the basis of proposals by the Commission" from which the Council could depart only by unanimity - rather than as mere recommendations that could be abandoned with qualified majority. The Commission would also like to issue direct warnings to the Member States concerned, rather than to submit a recommendation to the Council, which is then free to adopt it or not by qualified majority.

This argument too is not convincing, although the premise is correct. It is true that the Stability Pact could inhibit the automatic stabilisers and impart a procyclical bias to fiscal policy. In principle this need not happen, if governments are sufficiently farsighted to stay away from the 3 percent ceiling of the Pact. But will they be farsighted enough? The Stability Pact is needed to discipline myopic governments. Such governments are likely to remain close to the upper threshold of 3 percent and will not leave enough margins to absorb cyclical fluctuations. But if this was the main reason to transfer more discretional power to Bruxelles over fiscal policy, a simpler solution would be to reformulate the budget deficit ceiling in terms of cyclically adjusted budget deficits (in this case probably lower than 3 percent of GDP). This would allow the cyclical component of the budget to absorb income fluctuations, even if a country remains close to the ceiling tolerated by the Pact. Indeed, such a formulation would be an improvement over the current one, precisely because it is less likely to lead to pro-cyclical fiscal policies.

But there are deeper and more fundamental problems with the Stability Pact. The Pact has two possible motivations. One is that constraints on national fiscal policies are needed because of the negative externalities associated with undisciplined and myopic fiscal policy in some Member States. Excessively large debts and the risk of financial crisis in some Member States could impose costs on other Euro-area countries, in the form of higher interest rates or depreciated currency. But this externality has obviously little to do with deficits in excess of 3 percent of GDP. To address the externality, the Stability Pact should focus much more on longer term indicators of fiscal sustainability, such as the stock of public debt outstanding and the liabilities implicit in public pension systems (Pisany-Ferry, 2002, convincingly advocates these kinds of reforms).

A second possible motivation for the Stability Pact is to correct not an externality, but a systematic political distortion: fiscal rules and constraints are needed anyway, because democratically elected governments are myopic and would otherwise run excessively large budget deficits. It is not obvious that such a distortion is present in all political systems, though it seems to be more frequent in the proportional-parliamentary systems that dominate in Continen- 
tal Europe. ${ }^{2}$ But if this is the motivation, again the current formulation of the Stability Pact is not appropriate. Rather than forcing all countries to give up fiscal sovereignty to meet the straightjacket of a balanced budget, a more sensible solution would be to try and address the political distortions directly, with institutional remedies at the national level. This could be achieved in a variety of ways, for instance through budgetary procedures that increase the bargaining power of the Treasury minister, or imposing stringent requirements on the transparency and long-run perspective of budget accounts, or relying on the Commission's expertise to classify spending and revenues in various categories, such as capital vs current, or permanent vs transitory sources of revenues, or to estimate the impact of the business cycle on budgetary accounts (Wyplosz, 2002, formulates specific proposals along these lines). Moreover, even if one were to retain the approach of the Stability Pact, of targeting specific policy outcomes, the emphasis on the budget deficits and the neglect of the longer term generational imbalances is not justified. For instance, consider a pension reform that gradually but permanently reduces pension outlays in the future, but immediately cuts social security contributions so as to relax political constraints. A transition from a pay-as-you-go towards a fully funded private pension system could have this effect. Such a reform could run against the Stability Pact as currently formulated, no matter how desirable from an economic point of view. Similar criticisms apply to the current neglect of the composition of outlays spending into current and capital spending.

Before strengthening role of the Commission as a guardian of the Stability Pact, these problematic aspects of the Pact should be improved. Otherwise, it would be easy for recalcitrant governments to criticise the Commission for forcing them to comply with inefficient and defective rules. But even with these reformulations, enforcement of the Stability Pact would remain a complex exercise that cannot be carried out automatically. Some escape clauses, exercised through discretionary collective decision making as in the current framework, may offset the unavoidable distortions of the Stability Pact formulations.

\section{Summary}

The upshot of this discussion is that there is no need to increase the degree of centralisation of fiscal policy. The benefits of co-ordinated aggregate demand management are small. The primary emphasis should be to let automatic fiscal policy stabilisers work. For this purpose, reforms of the Stability Pact are

2 This is what emerges from the empirical study by Persson and Tabellini (2003), linking constitutional features to various aspects of fiscal policy in a large sample of democracies. 
needed. Giving the Commission a stronger role in enforcing the Pact as currently formulated would be counter-productive. Member States would feel deprived of a valuable policy instrument, in the name of an institution that makes little economic sense.

\subsection{Public goods}

Very few public goods are centrally provided in the EU. Despite some recent efforts at co-ordination, defence, foreign policy and internal security are largely national tasks. So is public transportation. There is some centralisation of tasks in education, research and culture and in environmental policies, but they amount to small thing. Immigration policy and border patrols are also decentralised.

\section{More or less centralisation?}

From the perspective of cost and benefit analysis, it seems likely that there would be large payoffs to more central provision of public goods in the areas of internal security, border patrols, immigration policy, and for aspects of foreign and defence policy. The abolition of borders between EU countries carries with it the need to centralise aspects of law enforcement against organised crime. Moreover, the recent terrorist attacks have made it absolutely clear that the challenges in these areas are global and require a co-ordinated European response. In terms of the language used in the previous section, the positive spillover effects and the economies of scale for foreign and defence policy, internal security, border patrols and immigration policy are very large. At the same time, the heterogeneity of preferences across countries in these areas does not seem very acute, at least relative to that present within each country. This point is confirmed by the recent Eurobarometer surveys depicted in Figures 1 and 2. About 73 percent of EU citizens want a common defence and security policy, over 65 percent want a common foreign policy. This should be contrasted with a rather lukewarm support for EU membership (about 50 percent) inside the EU15. Citizens in the 13 candidate countries display similar opinions, though their support for EU membership is stronger. The support for joint decision making in the fight against international terrorism, organised crime, drugs, is even stronger: around $70-80$ percent in both the EU15 and the 13 candidate countries $(\mathrm{AC} 13){ }^{3}$

3 The sources for Figure 1 are the Eurobarometer surveys conducted in April 2001 and in October 2001, N. 55 and 56 respectively; the sources for Figure 2 are the Eurobarometer surveys conducted in October 2001, N. 56, and the Eurobarometer surveys for the candidate countries conducted in October 2001. 
Naturally, these opinion polls could overstate the degree of preference homogeneity, particularly for defence and foreign policy. They suggest that the vast majority of EU citizens would support having a common policy, but they don't say whether they would really like the same policy. In practice, the absence of solid political and historical ties among people of different nationalities advises in favour of caution and gradualism, since the tolerance for differences of opinion and the desire of accepting the wishes of the majority in the realm of foreign and defence policy could be much lower than within nations. Nevertheless, compared to the status quo of virtually no integration in these policy areas, more transfer of sovereignty towards the centre is clearly desirable.

\section{Figure 1}

Support for key issues and for EU membership

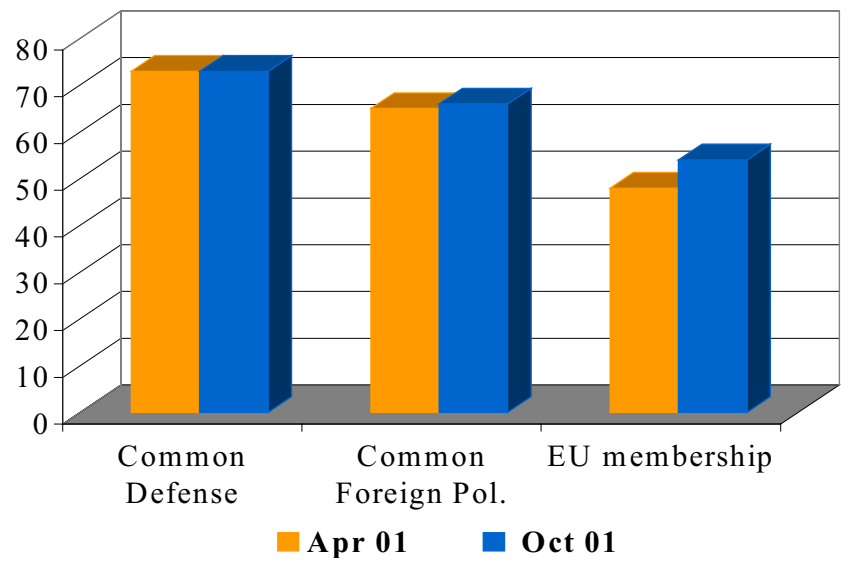

In the case of the other public goods (education, culture, research, health, transports), the perceived benefits from central provision seem much smaller. On the one hand, heterogeneity of tastes is more important and local information is more relevant. On the other hand, economies of scale and positive spillover effects across countries are much less obvious. The case for central provision of these other public goods is accordingly weaker and the status quo is likely to be adequate. By the way, in many cases this is also the opinion of most citizens as revealed by the Eurobarometer surveys. 
Figure 2

Support for joint decision marking

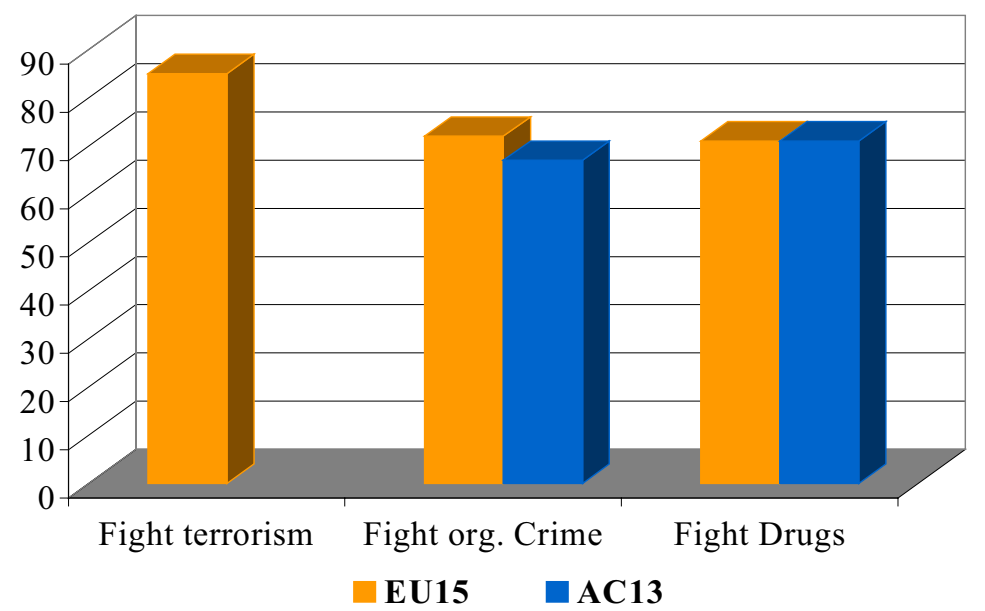

\section{Instruments of centralisation}

What are the instruments for centrally providing public goods in the areas of defence, foreign policy and internal security? Certainly, we should get rid of the illusion that co-ordination between national governments would be enough. The general reason is that, as with all public goods, individual Member States have strong incentives to free ride. Central public good provision must be enforced, and mere policy co-ordination might be non-enforceable. To achieve effective public good provision in the areas of internal or external security, or foreign policy, there is no alternative but to delegate executive authority to a central European policymaker. I now discuss several more specific arguments that support this conclusion.

First, foreign policy, defence, security, border patrol, are all areas that concern the executive powers of governments. We are not talking about enacting some common piece of legislation, or exploiting the rule of law to abide by common rules. Policies in these areas concern specific executive actions that cannot be legislated, but entail discretional decisions. It is difficult to imagine how coordination over these discretional decisions can be effectively enforced. This is an important difference with respect to, say, agreements to enact nondiscriminatory legislation in labour markets or consumer protection, where verifiability is not a problem and the Court of Justice or the Commission has effective enforcement power. 
A second related difficulty is that policies in these areas are chosen by governments but often executed by specific bureaucracies: the military, a diplomatic corps, a border or police patrol. The EU currently does not have a bureaucracy that could execute such common policies. In other areas, where coordination exploits the rule of law, the EU relies on national bureaucracies. But given the discretional and unverifiable nature of actions in the domain of foreign or security policy, it may be difficult to enact a common policy without a proper EU bureaucracy. Take the example of border patrols. Now each member state decides how many resources to devote to this task. This implies a big free rider problem: why should Italy spend a lot of money and energy to patrol its borders if illegal immigrants who enter Italy are then likely to move to Germany or the Netherlands? Agreeing to common guidelines and tight immigration standards among the EU 15 is useless in these areas, as long as enforcement is left to unverifiable efforts of national bureaucracies. Enlargement will make the problem worse: the incentive to free ride on the others increases with the number of countries. Similar considerations apply to foreign policy. Developing an EU diplomatic corps is a first step towards having an effective European foreign policy. But here, diplomats of Members States often compete among each other to promote national exporters, and the Commission is almost useless. Thus, it is difficult to exploit the traditional vertical links between the Commission and national bureaucracies that instead have worked so well in other policy dimensions.

National politics further aggravates these difficulties. This is particularly evident in foreign policy. As shown above, European citizens are well aware of the need of a common European foreign policy. But when they judge their own government, they inevitably do it with the lenses of their own national interests. It would be foolish to do otherwise: only Italians vote to re-elect the Italian government; why should they worry about whether the Italian government actions were also beneficial to the French citizens? But if the mandate of national governments is to pursue the national interest, their perspective is distorted. National governments will always have a strong incentive to differentiate their own position from the rest of Europe, or to claim credit for individual success. But if everyone tries to bring "trophies" to show his voters at home, a common co-ordinated position is unsustainable.

The upshot of all of this is that, to achieve effective public good provision in the areas of foreign policy, internal and external security, immigration policy, one needs a specific set of instruments at the European level. While the exact nature of the instruments depends on the specific policy area, some general conclusions seem clear.

First, the executive powers of government in specific areas should be transferred to a EU policymaker that will have discretionary authority within some 
limits. Commercial policy is a good example of how this could be done: one Commissioner is delegated to negotiate trade policy with the rest of the world, within pre-established limits. National governments are prevented from taking part in these direct negotiations, even though they exercise some collective control over the trade commissioner. More generally, delegation could be to a member of the Commission, as in the case of trade policy, so that the traditional "Community method" can be exploited; or it could be to a representative of the Council - the so called "intergovernmental method". There is increasing agreement now that something like this must be done in the area of foreign policy. The main issue is whether delegation of executive authority should be to the Commission or to a representative of the Council.

A second related conclusion, relevant for aspects of foreign policy, is the need to appoint a single external representative for Europe in international organisations (the IMF, the World Bank, perhaps eventually also the UN), replacing national representatives. Obviously this would increase the influence of the EU in these organisations. The board of directors of the IMF is a good example. The executive directors representing the European states are often unable or unwilling to co-ordinate on a common position. One reason is that they are delegates of their own economics ministers and feel no strong need to seek a common position with the other European representatives. Another reason is that some European directors also represent other non-European countries. But whatever the reason, the result is that the IMF is often dominated by the US, even though the US has less votes than the EU 15 together.

Third, there would be benefits from creating an EU bureaucracy in charge of specific missions, or at least creating a network of national bureaucracies: increasing the size of the EU diplomatic corps, creating a European border patrol, units of a European police, perhaps even special EU military troops to be deployed in special circumstances. These EU bureaucracies could stem out of national bureaucracies, but their efficiency would be greatly enhanced if they were accountable and take orders directly from the relevant EU policymaker in charge of the specific policy area, thus overcoming the free rider problem mentioned above.

Finally, creating these instruments and paying for the provisions of these public goods would cost money. There is also a growing need for contingency funds to assist a common foreign and security policy in the event of sudden crisis. Currently, these public goods are financed by national budgets. This is highly inefficient: each member state has a strong incentive to "free ride" on the others and under-provide the public goods that benefit all. The natural solution is to bear the costs of public good provision out of the EU budget. Only then, the decision process is forced to internalise all the benefits. The financial aspect is particularly important in the case of defence, the more costly 
of these public goods. We are well aware of the widening gap between the military capabilities of the US and the EU. The gap also reflects differences of financial resources. The amount spent on defence by the European countries together is less than half of the amount spent by the US. If we take R\&D spending on defence, the gap is even larger: Europe spends only about one fifth of what the US spends. The gap is widening, and it has reached the point where European countries are no longer even capable of co-operating with the US in military operations. Again, this reflects a free rider problem. Why should Spain spend on defence, if it can free ride on the UK?

But it is not only free riding. There are also important economies of scale that could be exploited much more effectively. Each individual European state is fully aware that it cannot have a military and strategic role on a global scale, it is just too small. Hence the perceived benefits of spending in defence and foreign policy are limited. But combining the resources of the EU 15 together, the perspective could be very different. The EU could have a role to play, imposing its vision and defending its interests, rather than always accepting the dominance of the US on strategic global matters. Economies of scale could be exploited even further with enlargement: once countries in Central and Eastern Europe have joined, the population of the European Union will reach half a billion. With or without a defence capacity, the Union is bound to have a large impact on the outside world.

\subsection{Redistribution}

Redistributive policies remain fully in the hands of national governments. There are nevertheless three important aspects of current EU policies that directly or indirectly hinge on redistribution.

Structural and Cohesion Funds. They are transfers from the EU budget to poor regions in Europe. Eligible recipients are national governments (for Cohesion Funds) and individuals in poor regions (for Structural Funds). They are negligible as a fraction of EU aggregate income, but very large for some of the receiving regions. They are also a large fraction of the EU budget (over one third).

The official goal of these programs is to foster economic convergence of the poor regions that might be hurt by closer economic integration. But careful empirical studies have shown that, on average, structural and cohesion funds have not influenced economic performance: from a statistical point of view, recipient regions have had the same growth rate (or the same unemployment rate) as the rest of the sample - see Boldrin and Canova (2001). There are some success stories in the use of Structural Funds, but there are also some utter failures. One can always claim that there are special reasons that can 
explain the failures (many of them concentrated in the Italian Mezzogiorno). But the opposite argument can also be made: some of the success stories, such as Ireland, are special too. If the goal of these programs was to accelerate economic convergence of poor regions, on average this goal has been missed

More likely, the main goal of structural and cohesion funds was redistributive: not to increase economic efficiency, but to redistribute the benefits of integration among countries. Two redistributive purposes were prominent: to provide side payments so as to facilitate compromise in bargaining situations, and to achieve some redistribution from rich to poor countries or regions - see Pindor (2001). The question is whether the same goals could have been achieved in less distorting ways.

Consider first side payments to smooth negotiations and facilitate Pareto improving deals. Participants at the bargaining table are countries, not regions. Side payments are thus needed among countries, not among regions or groups of individuals. Given the already high tax distortions throughout the EU, the value of government revenues is extremely high. This suggests that the most efficient way to transfer funds among countries is by means of lump sum intergovernmental transfers across EU governments with no conditions attached, pretty much as currently done with cohesion funds (but not with Structural Funds). Tying such funds to specific uses, or trying to identify from the centre who are the most worthy recipients, is likely to add inefficiencies. If national governments need to buy consensus at home to promote European integration (eg., building infrastructure in poor regions), they can find efficient ways to do that without any constraint imposed by the EU. ${ }^{4}$

Similar arguments apply if the primary purpose of redistribution is to equalise incomes. Here too, there is no reason why redistribution should take the form of direct transfers to individuals, while inter-governmental transfers seem simpler and more efficient. The political institutions of the EU are probably less able than those of Member States to cope with the stress of redistributive struggles. Moreover, the legitimacy and acceptability of redistribution in favour of citizens of other Members States is limited, compared to the sense of mutual solidarity inside each nation. Finally, the criteria that should inspire EU wide redistribution directed to individuals are not at all clear. Why should funds be targeted to poor regions, and not to poor urban areas? And why not to areas that are undergoing economic restructuring or areas hit by unexpected

4 An example of an inefficiency induced by Bruxelles is the recent Commission's proposal to use Structural Funds to subsidize broadband deployment in rural and remote areas. This idea is a big bonus for the cash stripped telecom industry, but has little economic rationale. There is no evidence that market forces are unable to develop internet infrastructures where needed. Rather that spending taxpayers' money to help ailing industries, the Commission should instead force governments to develop competitive access to networks through deregulation. 
calamities (a flood, an earthquake)? Raising these questions makes it evident that they should not be answered at the European level. All Member States have well functioning political systems and a variety of redistributive instruments at their disposal. It is up to them to decide how, to whom and how much to redistribute. In this case, the prescriptions of the theory of fiscal federalism, that redistribution ought to be centralised, seem inapplicable, at least in the near future. Of course, these arguments do not rule out redistribution from rich to poor Member States for the purpose of equalising the average per capita income of Member States, leaving redistribution inside each Member State a national prerogative. The purpose of achieving some income equalisation inside the Union could still be achieved, by calibrating the net intergovernmental transfers on Member States average per capita income.

The imminent enlargement adds further reasons to scale down or reconsider the "acquis communautaire" on Structural Funds. On the one hand, many residents of the poor regions in the EU 15 will be deprived of Structural Funds and will cry for help. Several poor regions of the EU 15 will no longer be recipients of Structural Funds, because the funds will be reallocated to the poorer new entrants. According to the Commission, as many as 37 million people live in regions of the EU 15 that will lose the eligibility status for Structural Funds once the Union grows to 25 Member States (Commission, 2002b). As a result, Structural Funds will become much more concentrated among a few regions of the 15 existing Member States. Swallowing this "withdrawal crisis" without political tensions and without increasing the budget devoted to Structural Funds could be difficult.

On the other hand, recipients of Structural Funds in the new Member States are likely to feel cheated and disappointed. To limit the redistributive flows in favour of the new and much poorer Member States, it has already been agreed that total transfers received cannot exceed 4 percent of national GDP for any country (somewhat hypocritically, the Commission refers to the ceiling as reflecting limits in the "absorptive capacity" of the new entrants, rather than the reluctance of richer Member States to open the purse - Commission, $2002 b$ ). While 4 percent is a relatively large fraction of GDP, aid will be diluted over a very large population, since whole countries will qualify as poor regions. As a result, the per capita transfers among the poor regions of the new Member States will be much smaller than in the existing Member States (where instead transfers are concentrated in just a few regions). Will the citizens of Central and Eastern Europe accept this, or will they feel that their expectations have been betrayed? The latter outcome is quite possible. Politicians in these countries have probably over-sold the economic benefits from joining the EU. The Eurobarometer surveys show that citizens in Central and Eastern Europe already have very high expectations of drawing economic benefits 
from EU accession. These expectations are likely to be disappointed, at least in the short term.

All of this suggests that Structural Funds, far from being an instrument of solidarity with which to diffuse tensions between rich and poor, are likely to become a new source of political complaints and disappointments once enlargement takes place. So far, radical reform of Structural Funds has been discouraged by the simplistic argument that they are part of the Acquis Communautaire, and as such they are almost sacred (Commission, 2002a). But now is the time to think more boldly. A simple solution would be to scrap Structural Funds entirely among the current EU 15 countries, re-inventing them from scratch on an East-West basis only and on the basis of transfers to countries, not regions.

Common Agricultural Policy (CAP.) This is a large and complex set of policies that indirectly or directly transfers income to the agricultural sector and absorbs almost half of the EU budget. These policies have been reformed repeatedly, and the process of reform is still ongoing.

There is unanimity among economists that reforms in this area should be accelerated and completed, transforming CAP from a price fixing to an income support program for farmers, so as to remove the distorting effects and the inefficiencies of price controls. Once this transformation is achieved, there is no longer a valid reason to keep CAP a special EU competence. Income support to farmers could be more effectively carried out by national governments, respecting the guidelines of the Single Market to avoid distorting competition. To the extent that some countries are net losers or net gainers in the reform process, appropriate compensation can be found through intergovernmental transfers. Here too, of course, enlargement adds urgency to this problem.

Social Charter It is widely believed that closer integration and more intense economic competition threatens the survival of the European welfare state and would reduce assistance to the poor and to those in need. Hence the need for policies that impose a minimum level of social protection, or seek to harmonise aspects of labour market legislation, so as to avoid "social dumping" and a "race to the bottom".

But the idea that the European welfare state is threatened has little empirical support. The process of European economic integration has not led to any dismantling of the welfare states so far, on the contrary. Some of the European countries that are more open and, by international standards, more competitive, are typically those of Northern Europe, where the welfare state is larger, more pervasive, and more geared towards assisting the poor. By contrast, the countries in Southern Europe have both smaller and more corporatist welfare states, and much lower ranking in all statistics of international competitiveness. 
Clearly, market pressures force all countries to become more efficient. But the idea that this would lead to a dismantling of the European welfare states is a conjecture not born out by the facts.

Still, it is true that stronger market forces and more intense competition impose limits on what governments can do. This is why national governments are keen to agree to harmonise aspects of social policies, restricting competition in specific areas. But often, the goal of these restrictions and efforts at harmonisation is to preserve privileges of powerful special interests, not so much to protect the poor or the weak. If social policy and labour market legislation was enacted by benevolent social planners, harmonisation and limits to "social dumping" could indeed be desirable. But such is not the case. The European unemployment and its low rate of growth are primarily a political problem, not an economic problem. They are caused by labour market rigidities and high taxes on labour income, often imposed by powerful trade unions representing "insiders", workers close to retirement or even pension recipients. If more intense competition leads to a dismantling of such rigidities, Europe as a whole can only benefit. But we should be aware that special interests and opportunistic politicians will try to resist this competition of regulatory systems, imposing harmonisation and minimum standards even if this runs against the general interest. The risk of excessive centralisation in this area is considerable.

Some co-ordination of EU social policies may still be desirable, however, to reinforce benchmarking. Citizens are generally well aware of the unsustainability of pension systems in the face of an aging population, and of the inefficiencies of some aspects of labour market legislation. There is agreement on the need and the urgency of reforms. But there is disagreement over how to reform, and procrastination is tempting. Reforms abroad often spur reforms at home: they put pressures on hesitant governments and provide information on which reforms work and which do not. Hence, some elements of benchmarking and some common goals can help in the current circumstances. This can be achieved through efforts at what is now called "Open Co-ordination Method", without any transfer of sovereignty to the EU - see Micossi (2002) for an extensive review of alternative co-ordination methods in the EU.

\section{Summary}

This discussion leads me to the conclusion that the role of the EU in the realm of redistribution should be decisively scaled back. With regards to national social policy, the EU should avoid efforts at harmonisation. And direct redistribution by the EU should mainly be confined to transfers across national governments, largely on an East-West basis to smooth the accession process. The primary role of such transfers should be to make sure that the benefit of 
European integration are spread fairly among countries. Fairness in integration is a prerequisite for smooth decision making and efficient bargaining among countries. But such fairness does not require redistribution to sectors, groups or regions within countries. National governments have enough tools at their disposal to achieve their desired domestic redistributive goals, without being forced to channel funds to specific groups of beneficiaries.

\subsection{The budget of the $\mathrm{EU}$}

Currently the EU budget is mainly devoted to finance the redistributive programs of the EU. Out of a budget which is just over 1 percent of the Union GDP, almost half is spent to support agriculture, while another 35 percent are transfers to poor regions. Marginal revenues take the form of transfers from Member States.

Both features give the EU budget a strong redistributive focus. Now the whole discussion on the EU budget only concerns who gains and who loses, and in particular which countries are net beneficiaries or net payers, and by how much. No attention is paid as to whether the money is well spent for the average European tax payer, or whether reallocations across alternative programs are desirable. Enlargement, with the large disparities between rich and poor countries, will make the political debate on the EU budget a nightmare.

In light of the discussion in the previous two sub-sections, it would make much more sense to shift the focus on what is the appropriate level of public good provision, taking into account the cost of raising funds. On the side of outlays, this means spending for the public goods that are currently badly needed: internal and external security, defence, foreign policy. On the contrary, the redistributive programs currently alive should be scrapped, scaled back or isolated in a separate section of the budget.

On the revenue side, these public goods could be financed with the proceeds of a European tax levied for the purpose. For instance, a fraction of the personal income tax base, or of the value added tax base, could be reserved for a specific EU tax. In a way, this would be a return to the past: until 1988 the EU budget was paid for by a small fraction of the VAT tax. The tax rate on the agreed upon tax base could be set by the Council and the European Parliament under some qualified majority provision - see Goulard and Nava (2002) for a more extensive discussion of how this could be done in practice.

Such a financial arrangement would have several advantages. It would focus the mind of politicians on what is the appropriate level of public good provision, rather than on who can bring home bigger trophies to show to his voters. 
Giving the European Parliament more say over the budget, and creating a specific tax over which the European Parliament has some control, would also stimulate a European-wide debate on genuine European policy issues: how much are we prepared to spend to have a more effective military capability, or a more efficient border patrol? Now, political debates on these issues are inevitably distorted by a national perspective and by the debate on redistribution across countries. Finally, having a European tax earmarked for concrete and specific European public goods would increase the transparency and legitimacy of EU decisions on those matters.

This idea, of providing specific European public goods in the realm of security, defence and foreign policy, out of a common EU budget financed by a specific European tax, is quickly gaining ground in several circles. The recent Communication of the Commission to the Convention (Commission, 2002a) implicitly formulates a proposal of this kind. But this idea, as sound as it is, stumbles against an important objection. How do we know that a European tax will not be abused to finance redistributive transfers that disproportionately benefit some groups or some countries? After all, this is exactly what the EU budget is currently being used for.

In principle, this could be prevented by earmarking the tax proceeds for specific public goods, and prohibiting their use for redistributive purposes. Redistributive programs could still be financed by means of transfers from Member States. But the promise that the proceeds of a European tax will not be diverted for redistribution would be much more credible if the purely redistributive programs of the EU budget (CAP and Structural Funds) were scaled down or deeply reformed. As argued above, these programs are inefficient and deserve to be reformed anyway, particularly in view of the imminent enlargement. But there is an additional argument to do so with urgency. Their mere existence in the current form raises legitimate suspicion on how the EU budget would be spent if more resources were available. Thus, these programs are a political obstacle to the creation of a more efficient system of providing and financing badly needed European public goods.

\section{The Commission vs the Council: who should be doing what?}

The task reallocations discussed in the previous section and the imminent enlargement have important implications for how to reform the EU institutions. Centralisation of new tasks and the entry of several new Member States may require the creation of new institutions, or the reform of existing ones. This section discusses some important tradeoffs in institution design. Given the complexity of these issues, there is no pretence of completeness. 


\subsection{Bureaucratic accountability and democratic accountability}

One reason why EU integration has been so successful is that centralisation has meant much more than simple policy co-ordination. It has meant designing institutions that make it possible to transfer sovereignty to the centre. Integration has proceeded gradually, one policy dimension at a time, tailoring the institution to the specific policy area over which integration was needed.

A remarkable feature of EU integration so far is that centralisation has preserved important dimensions of accountability and control. But it is important to appreciate the particular way in which accountability for EU decisions has been preserved, and how it differs from political accountability in representative democracy.

In a representative democracy, elections are the ultimate instrument for holding politicians accountable. Citizens delegate decisions to representatives (governments, legislators). If they are not satisfied with the decisions taken, the delegation is not renewed: the majority loses the elections and is replaced by a new government or a new majority in Parliament.

This mechanism cannot work in the EU, at least not under the current European constitution. Governments are the key decision makers in the Council. But they are accountable to citizens at home, in national elections, and they are primarily judged for their domestic performance, not for EU decisions. And other EU policymakers (the European Central Bank or the Commission) are appointed, not elected.

Accountability in the EU has been achieved, instead, through methods that are typical of bureaucratic control, not of political control. Transfer of power to a EU body has generally been accompanied by a clear operational definition of the policy goals. EU policymakers (the ECB, the Commission, the majority in the Council) generally have a narrowly defined "mission": price stability, enforcing the single market, holding prices of agricultural commodities stable. This has two advantages. On the one hand, it limits discretion by the EU policymakers, and hence insures that power transferred is not abused. On the other hand, it facilitates ex post control. The European Parliament, the media, the Council, can blame or approve the way in which EU decision making power has been used. Since EU policymakers have a narrow mandate and their decisions are often inspired by external technical criteria, they can be held accountable for their behaviour despite the absence of elections.

This method of bureaucratic control has worked well so far in the EU. Probably, it can be fruitfully extended to the realms of immigration policy or internal security. Here, it seems possible to define a precise mission for EU policymak- 
ers, exploiting the Commission and designing appropriate technical guidelines to achieve clearly defined operational goals.

But can the method of bureaucratic control also work in the other new areas where further centralisation is most urgently needed, foreign policy and defence? It seems very unlikely. As argued above, here a transfer of executive powers with open ended and discretional decision making is really needed. What mandate can be given in the realm of foreign policy? The only feasible mandate is to pursue the common interest of the EU. But what does that mean in practice? If the mandate is so incomplete and it leaves so much room for discretional judgement, there is only one way to hold policymakers accountable: through democratic elections. Only citizens can tell whether policy decisions are really in their own interest. Unfortunately, as argued above, this instrument of control is unavailable at the EU level, or at least it is seriously deficient.

\subsection{The Intergovernmental method vs the Community method}

We are thus left with a fundamental problem. Europe is now in a situation in which there would be major benefits in centralising foreign policy and defence. But in this policy area, bureaucratic control cannot work. To centralise aspects of these policies, a drastic redesign of the EU political constitution might be needed. Europe might need political institutions that are more typical of a federation than of a confederation of states. It is no coincidence that historical episodes of unification of countries have indeed coincided with situations in which external threats or a common enemy created large benefits from centralising defence and foreign policy. But is Europe ready to jump to much closer forms of political integration? And if the answer is negative, as likely, what can be done about it? These are the most difficult questions with which the Convention on the Future of Europe is struggling.

Two very different approaches are possible, and two camps have formed in this debate. One possibility is to transfer more executive powers to the Commission, while at the same time "politicising" the Commission by imposing more democratic control over its appointment. The opposite approach is to reinforce the Council, increasing its ability to co-ordinate national policies and provide public goods.

The second approach (the so called inter-governmental method) is the least traumatic and more likely to be pursued in the end. One important idea, suggested by political leaders in France and the UK, is to replace the rotating six months Presidency of the Council with a stronger President elected by all EU leaders for several years. The new President would be the official representa- 
tive of Europe abroad (replacing the position currently filled by Javier Solana), and would act as the agenda setter for the Council in developing defence and foreign policies with a European perspective. This approach would have the merit of leaving these sensitive policy areas firmly in the hands of Member States, while at the same time providing new instruments for tighter and more effective policy co-ordination.

But there are also several drawbacks. First, it is unlikely that the limits of policy co-ordination would be overcome. The incentives of national political leaders to differentiate themselves from the others or to signal their competence to voters at home are just too strong. Each government will want to show that it is pursuing the national interest, or seek to claim credit for EU policy successes. A unified and effective foreign policy would likely remain an elusive goal.

Second, the EU would continue to rely on national bureaucracies for public good provision. But, as argued above, lack of verifiability implies that the free rider problems would not be addressed. The Commission, not the Council, is traditionally the bureaucratic arm of the EU. The Council cannot adequately monitor the effort and the resources that each government devotes to perform the common tasks in, say, internal or external security, or to exchange information collected by national diplomacies. As a result, each country will continue to free ride on the others.

A third important problem with this approach is that the Commission would loose power of initiative and its role could be reduced to that of a "Secretariat" of the Council. This is negative because the Commission is also the "Guardian of the Treaty". A less powerful Commission may not be able to enforce the Single Market against recalcitrant Member States, to ban state aid, to impose budgetary discipline on myopic governments, to negotiate effectively with foreign countries over trade policy or other aspects of common economic policies. The EU (perhaps) would become stronger in some areas, but it could become much weaker in others.

Finally, it is not obvious that strengthening the Council in this way would increase democratic legitimacy and accountability. On the one hand, the Council President would be appointed, not directly elected. European citizens would remain suspicious of the closed door negotiations that led to his appointment. On the other hand, there remains the "bundling" problem: national governments will still be judged mainly for what they do at home, not for their European policies. Thus, we would still lack an instrument of democratic control to correct possible mistakes in European policies, or to express the voters' dissatisfaction with the conduct of European affairs. 
The alternative approach is to transfer some executive powers to the Commission, but then to increase its political accountability. This is the approach most likely to be favoured by the smaller European Member States (who fear being emarginated in the Council), by several representatives in the European Parliament, and perhaps by the Commission itself.

The Commission recently formulated some proposals to the Convention that go in this direction (Commission, 2002a). The idea is to extend the traditional Community method to new areas: to strengthen the position of the Commissioner for External Relations, merging its functions with those of the High Representative for Common Foreign and Security Policy (Javier Solana) and exploiting this single position for external representation of Europe; to reinforce the Commission initiative over foreign and security policy; to provide new human and budgetary resources for a common foreign policy and for security policy; to abandon unanimity rule in the realm of foreign policy (though not of defence). These are bold proposals that would enable effective public good provision in these areas, but which will be fiercely contested by national governments. Their merit is just the other side of the weaknesses of the intergovernmental approach: the Commission would be reinforced, a European bureaucracy would be revamped, initiative would be unified and taken by a body who cares about European interests and not national interests.

Surprisingly however, these bold proposals by the Commission were not accompanied by an acknowledgement that the Commission itself needs to become more democratically accountable. Acquiring such strong executive powers from national governments would be unthinkable without some form of democratic control over the Commission.

But here is where the difficulties arise. So far the Commission has been a bypartisan and largely technical body. Preserving this feature is important if the Commission is to remain an effective "Guardian of the Treaty". But how can the Commission become more democratically accountable without also becoming more partisan?

A possible compromise, advocated by some commentators, is to reverse some aspects of the current procedure for appointing the Commission (Padoa Schioppa, 2002). Rather than the Council nominating the President of the Commission and the European Parliament confirming it, the opposite could take place. The Parliament elects the President after each European election (so that citizens vote at European Parliamentary elections knowing who the alternative candidates for President are). And the Council by qualified majority then confirms the Parliament's choice. To preserve by-partisanships, the rest of the Commission could then be appointed as now by the Council and the President, and confirmed by the Parliament. Alternatively, and more radically, the 
Commission President could be directly elected by European citizens (rather than by the Parliament).

Understanding the tradeoffs between these alternative methods (or others) for increasing the democratic accountability of the Commission is important. Certainly more ideas and proposals will be put forward in the ongoing debate on the Future of Europe. But the crucial question in the end will be whether European citizens have enough in common to develop tighter forms of political oversight of their common policies, or whether instead language and cultural barriers are so strong that, at least for now, the intergovernmental method is the only safe approach.

\section{What compromise?}

It is very difficult to predict what will come out of the current process of reform. But some compromises are inevitable. There are two main dividing lines in the ongoing debate. One pits the advocates of centralisation against the advocates of subsidiarity. The other concerns the contrast between the Intergovernmental method and the Community method. These two divisions are correlated, though not identical. Many issues are on the table, and many different compromises are possible. Some would be highly desirable, others could be disastrous.

September 11 and the recent events in the Middle East have increased the demand for a more effective "external Europe" and stronger European responsibilities in internal and external security. A shift towards more public good provision at the European level seems likely, though the institutional form that this could take is still highly uncertain. As argued above, this shift would be highly desirable.

But in the name of finding a compromise and avoiding a European Superstate, something else might have to go in the opposite direction: from Bruxelles back to the national capitals. In the previous pages we argued that this opportunity should be seized to reform the redistributive programs of the Union: mainly $\mathrm{CAP}$ and the Structural Funds. This would make it easier to rationalise current financial arrangements: the EU budget would be devoted to providing public goods and could be financed by a specific European tax. Redistribution could mainly or exclusively be directed to assist the new accession countries and provide side payments to compensate the countries who would be net losers from agricultural reform.

This compromise on task allocation (more public good provision but less redistribution at the European level), could take place while also strengthening 
the role of the Commission. The Commission could become the agenda setter and the enforcer for public good provision, as the Community method is extend to the second and third pillars (foreign policy, home affairs, internal and external security). And its enforcement powers over the single market could be strengthened. As argued above, however, a more powerful Commission would also have to become more democratically accountable to European citizens at large, not just to the governments in the Council. We would move towards a more federal Europe in some dimensions, while also stepping back from the danger of a European Superstate, concretely and not just with empty rhetoric.

But another compromise is possible and politically much more palatable: to keep the current redistributive programs alive and kicking, and instead to scale back the enforcement of the Single Market. This would leave national politicians more free to pursue their national goals in the name of subsidiarity. It would also avoid the political costs of hurting the current beneficiaries of European redistribution.

This scenario on task allocation would naturally go hand in hand with an overall weaker Commission. Governments would be in charge of public good provision in foreign and security policy, and the Council would be strengthened the intergovernmental approach. Public good provision would rely on policy co-ordination, and would probably be less effective. The Commission would be much less influential in all dimensions, including in its roles of "Guardian of the Treaty" and enforcer of the single market. In the short run some hard choices and some risks could be avoided. But the medium run result could be a serious step back, with new trade barriers, distortion of market forces, and less effective public good provision.

The main challenge for the Convention on the Future of Europe is to influence events so that the first, better, compromise in the end will be pursued.

How should tasks be divided between the EU and its member states? And what institutional reforms are needed? This paper argues that the single market remains to be better enforced, and this might require further centralisation of tasks. On the other hand, EU meddling with redistribution should be scaled back; this would imply reducing EU intervention in agricultural policy, structural funds and the social charter. EU tasks should instead be expanded outside the first pillar, namely in foreign and defence policies, internal security, immigration. The paper ends by discussing what institutional reforms are needed to accompany this allocation of tasks. 


\section{References}

Alesina A., I. Angeloni and F. Etro (2001), "The political Economy of International Unions", CEPR Discussion Paper no. 3117.

Alesina A. and I. Angeloni (2001), "What does the European Union Do ?", NBER Working Paper, May.

Alesina, A., O. Blanchard, J. Gali, F. Giavazzi and H. Uhlig (2001), "Defining a Macro-economic Framework for the Euro Area", CEPR Report on Monitoring the European Central Bank no. 3, March.

Boldrin, M. and F. Canova (2001), "Inequality and Convergence: Reconsidering European Regional Policies", Economic Policy (32).

Buti, M., D. Franco and H. Ongena (1997), "Restrospective application of the 'Stability and Growth Pact' to the post war period", Recherches Economiques de Louvain 63(4), 321-366.

Commission (2002a), Communication from the Commission - A Project for the European Union, Bruxelles, May 2002, COM(2002) 247 final.

Commission (2002b), Commission Communication - First ProgressReport on Economic and Social Cohesion, Bruxelles, January 2002, COM(2002) 46 final.

European Forecasting Network (2002), EFN Report on the Euro Area Outlook - Autumn 2002 - coordinated by Marcellino, M., IGIER; www.efn.uni-bocconi.it

European Parliament (2002), Division of Competences between the European Union and the Member States, P5_TAPROV(2002)0247.

Fatàs, A. and I. Milhov (2002), The case for restricting fiscal policy discretion, mimeo.

Goulard, S. and M. Nava (2002), "Un financement plus democratique du budget européen: un défi pour la convention européene", Revue Française de Finances Publiques 80.

Gros, D. and A. Hobza (2001), "Fiscal Policy Spillovers in the Euro Area: Where are they?", CEPS working document no. 176.

Jacquet, P. and J. Pisani-Ferry (2001), "Economic Policy Co-ordination in the Euro-zone: What Has Been Achieved? What Should Be Done?", CER Essays, January.

Micossi, S. (2001), Building a More Dynamic Europe, mimeo, Assonime. 
Micossi, S. (2002), "The Mandate of the Convention", in: EuropEos, Institutional reforms in the European Union-Memorandum for the Convention, Rome.

Micossi, S. (2002), Economic Policy Coordination and Policy Regimes in the $E U$, Assonime, Note e Studi n. 35, July.

Oates, W. (1999), “An Essay in Fiscal Federalism”, Journal of Economic Literature, September.

Padoa Schioppa, A. (2002), "Improving Effectiveness of the Institutions", in: EuropEos: Institutional reforms in the European Union - Memorandum for the Convention, Rome.

Persson, T. and G. Tabellini (2003), The Economic Effects of Constitutions: What do the Data Say?, MIT Press, forthcoming.

Pinder, J. (2001), The European Union - A Very Short Introduction, Oxford U P.

Pisany-Ferry, J. (2002), Fiscal Discipline and Policy Coordination in the Eurozone: Assessment and Proposals, mimeo, April.

Tabellini, G. (1990), "Domestic Politics and the International Coordination of Fiscal Policies", Journal of International Economics 28.

Tabellini, G. (2002), "The allocation of tasks", in: EuropEos: Institutional reforms in the European Union-Memorandum for the Convention, Rome.

Vaubel, R. (1985), "International Collusion or Competition for Macroeconomic Policy Coordination”, Recherches Economiques de Louvain 51.

Vaubel, R. (1995), Monograph by the Institute of Economic Affairs, London.

Wyplosz, C. (2002), Fiscal Discipline in EMU: Rules or Institutions?, paper prepared for the April 16, 2002 meeting of the Group of Economic Analysis of the European Commission, April. 